\title{
微細穴の加工と計測
}

\section{微細穴加工と計測の最前線* \\ Forefront of Micro-hole Machining and Measurement}

\section{増沢隆久** 高増 潔***}

Takahisa MASUZAWA and Kiyoshi TAKAMASU

Key words microhole, minute hole, nozzle, machining, drilling, aspect ratio, measurement, micro CMM, probe

\section{1. 微細穴加エ一はじめに}

「微細」も「穴」も極めてあいまいな概念なので,「微細 穴」も最近広く使われる言葉でありながら，その意味する ところは対象とする事項によってさまざまである。加工の 分野では通常材料を貫通した空間または比較的アスペクト 比（深さ/直径）の大きいくほみを「穴」とみなしている. 「微細」に関しては, 現場では, 従来用いてきた装置で加 工するのに小さすぎれば $5 \mathrm{~mm}$ ぐらいでも「微細穴」とさ れることがあるが，本稿では「穴」のさしわたし（直径相 当）が $500 \mu \mathrm{m}$ 以下の場合を想定して述べることにする.

\section{2. どんな加工法があるか}

微細加工を可能とする必要条件は, 加工単位 (一つの加 工現象で除去/付加される材料の量）を小さくすることと, 除去/付加位置の精度を高くすることであるから，適用可 能な加工法は数限りなくある. 本特集で詳しく取り上げる ことのできる加工法はわずかであるが，この分野の現状と 将来について考える場合には, 一応主要な加工法の全体像 を把握しておくことが必要なので, その概略を記して おく.

微細加工に現に適用されているか, 適用研究が進んでい る加工法には大きく分けて次の三系統がある.

A. 工具を使う加工法

これは加工に扮ける形状指定要因 (SSF, Shape

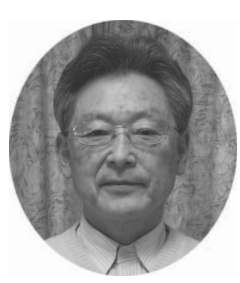

*原稿受付 平成 24 年 3 月 6 日

*正会員 MMTC（增沢マイクロ加工技術コン サルティング）（神奈川県相模原市南区相模大 野 3-11-17-403)

***正会員 東京大学大学院工学系研究科 (東京 都文京区本郷 7-3-1)

\section{增沢隆久}

1971 年東京大学大学院精密機械工学専攻修了. 工学博士. 各種手法によるマイクロ加工と計測 の研究・教育に従事、著書等は「やさしいマイクロ加工技術」(日刊工業新 聞社),「マイクロ加工技術 [第 2 版]」(日刊工業新聞社（共著）など. 高增 潔

1982 年東京大学大学院工学系研究科博士課程修了. 工学博士. 東京電機大 学工学部助教授を経て, 現在は東京大学大学院工学系研究科教授.
Specification Factor）として工具（の形状と移動軌跡）を 用いるもので，切削をはじめとする多くの手法が含まれ る、レーザのような映像工具もここに含めることにする。

B. マスクを使う加工法

これはSSF としてマスク（加工しない部分を覆い隠す） を用いるもので, 半導体製造工程などに多用される手法で ある. マスクでは穴の（材料表面に㧍ける）2次元的形状 のみを指定するので, 穴の内部形状等を指定するには何ら かの工夫を要する.

C. 特殊な加工法

穴を掘るという感覚とは異なるやり方で最終的に穴を入 手できる方法もいくつかあり, 用途によっては有用で ある。

\section{1 工具を使う加工法}

\subsection{1 切削}

穴加工の最も一般的な手法はドリルを用いる切削であ る。細いドリルを入手できれば微細穴加工が可能となる。 ただし, 切削の加工原理より, 材料を塑性変形により破壊 に至らせるので, 微小寸法になるほど転位による変形寄与 が減少するため, ドリルの素材は被加工物の素材よりせん 断弾性倸数の大きい材料でなければならない。このため超 硬合金など，高硬度材料のドリルが多用される。

ドリルは複雑な形状をしているので，いかに微細なドリ ルを実現するかが技術上のポイントとなる．現在では研削 技術の向上により微細なドリルが入手でき, セラミッ ク ${ }^{1)}$, ガラス ${ }^{2)}, \mathrm{Ti}^{2)}, \mathrm{SUS}^{2)}$ などに直径 $10 \sim 30 \mu \mathrm{m}$ 程度の 穴加工が可能である.

\section{1 .2 放電加工}

放電加工では工具形状が単純なので切削より微細加工へ の適用が容易である。しかし，一般の放電加工機では放電 のエネルギが大きすぎ, 微細加工には適していない場合が ある. 特に $100 \mu \mathrm{m}$ 以下の穴加工では，パルスエネルギを 絞った放電加工機でないと対応できない，そのような専用 機であれば直径 10～20 $\mu \mathrm{m}$ の穴加工は容易であるし ${ }^{344)}$, 簡易なものでも $30 \mu \mathrm{m}$ 程度まで対応できる ${ }^{5)}$ ，ただし，今 のところ導電性材料が対象である。 


\section{1 .3 電解加工}

電解現象を用いて材料を溶出させるのが電解加工であ る. 加工の際に力が加わらないことと加工面が滑らかなこ となどが特長で，パイプ状の工具電極を用いると非常に深 い微細穴の加工が可能である。最近は極短パルス（ $\mu \mathrm{s} \sim \mathrm{ns}$ オーダーのパルス幅）の電解加工技術が発展しつつあり, 直径数十 $\mu \mathrm{m}$ ほどの穴加工も可能となっている ${ }^{6)}$.

2.1.4 打ち抜き

上述のような穴加工技術でダイを作れば微細な打ち抜き も可能となる。型合わせには高い技術・技能を要するが, 比較的軟質な金属やプラスチックであれば直径数十 $\mu \mathrm{m} の$ 打ち抜きが可能である7).

\section{1 .5 レーザ加工}

レーザ加工はエネルギの集中注入が可能なので，高速の 穴加工に向いているが，微細加工の場合，熱影響層やドロ スの付着が難点とされてきた。しかし紫外レーザや超短パ ルスレーザではこうした欠点が少ないので, 微細穴加工へ の適性が高まりつつある。

\section{1 .6 超音波加工}

超音波加工は遊離砥粒を用いる加工であり，振動雲囲気 であることから加工くずの排出が容易であり，微細加工に 適している。 セラミックなどの硬脆材料に対しては有力な 手法となっており, 直径数十 $\mu \mathrm{m}$ の穴加工が可能である

\section{2 マスクを使う加工法}

\section{2 .1 エッチング}

加工しない領域をマスクで覆って，露出した部分のみを 腐食除去するのがエッチングである。液中で溶出させる方 法，真空中でスパッタさせる方法（ドライエッチング）な どがあり, 加工単位を極めて小さくできることから, 超微 細な穴加工が可能である。一方, 原子レベルの反応に基づ くため, 加工しやすい材料は限定される. 半導体素子の開 発により発展してきた手法であることから，シリコン等の 加工で特に重要な位置を占めている.

2.2 .2 電解加工

材料除去を電気化学的現象により行うのが電解加工であ る. 導電性材料に限られるが, ウエットエッチングと似た 特徴をもつ。

\section{2 .3 ブラスト加工}

砥粒を吹き付けることにより材料除去を行う手法であ る。従来比較的大きな対象が主であったが, 最近では微細 な砥粒を用いる技術も向上しつつあり, 直径数十 $\mu \mathrm{m}$ の穴 加工も可能になっている ${ }^{8)}$.

\section{3 特殊な加工法}

2.3.1 パイプの利用

ガラスや金属のパイプは加熱や伸延により非常に細くす ることができる。その際，内径も微細寸法になるので，こ れを他の材料の中に埋め込めば微細な穴を得ることがで きる.

\subsection{2 電鋳}

細いピン，ワイヤなどは比較的容易に入手できる。その
まわりにメッキによる金属層を成長させ，後からピンゃワ イヤを引き抜けば結果として細穴を形成することができ る。ピン材料としてはステンレス鋼など後で引き抜きが可 能なもの, あるいはエッチングや加熱・蒸発などで除去で きるものを選ぶ必要がある。

\section{3. 微細穴加工の現状と将来の方向}

\section{1 微細化}

細穴加工技術は長年にわたりさらなる微細化を追求して きた. 今後もその傾向は続くものと思われる.

上述のように多くの加工法ですでに直径数十 $\mu \mathrm{m}$ の加工 が容易に行えるレベルに到達している，基本的には工具の 微細化によりさらに一桁の微細化は達成されることがほぼ 確実である。実際，放電加工 ${ }^{9)}$ 11) および切削 ${ }^{12)}$ では数 $\mu \mathrm{m}$ の穴加工が実用となっている。もちろん，エッチングにお いては従前より数 $\mu \mathrm{m}$ の加工が普通に行われており, 最近 ではサブミクロンの加工も広く行われるようになった。ま た, 塑性加工で凹みを作り, 後処理を施すことで数 $\mu \mathrm{m}$ 径 の穴を得るという複合的手法も，紡糸ノズルを生産する工 程としてすでに確立している ${ }^{13) 14}$.

切削では切刃の先鋭化, 放電加工ではパルスエネルギの 微小化, 砥粒利用の手法では砥粒の微細化とその取り扱い 手法の開発, などにより, さらに微細化が進むものと思わ れる。

\section{2 高精度化}

穴径が小さくなるほど加工誤差の絶対值が大きく影響す るようになる。丸穴であれば直径と真円度, 貫通穴では上 下の直径差，また多数穴であれば穴相互間の位置誤差など が重要である。

工具を回転させるタイプの加工法では偏心, 振動等を抑 えて真円度を上げ，直径増大を抑えなければならない。放 電加工では工具の入り側と出側の直径差を抑える工夫が必 要である。また，ドリル加工では返りを抑制または除去す る技術を向上させる必要がある。

どの手法においても，工具の位置決めやパターンの寸 法・配置においてサブミクロンの精度を確保することが必 須である。 また工具自体の寸法精度も当然サブミクロンレ ベルでなければならない.

逆に, 微細穴加工で有利な点として, 加工に際して主軸 の動力が微小でもよいこと，また，全てにおいて機構が小 型でよいことが挙げられる。これらを精度向上に活用して いくことが重要であろう.

\section{3 高速化}

微細穴の場合，配列された穴など，多数穴加工が必要と なることも多い。したがって加工時間短縮は重要な課題で ある。レーザ加工など高速加工向きの加工法の精度向上に よる適用，あるいは切削や放電加工などの高精度加工法の 高速化による適用などのアプローチが考えられる。

\section{4 深穴化}

タービンブレードの冷却孔に代表される微細深穴加工は 
引き続き重要な技術である。より広い方面で深穴加工の要 求は高まりつつある.

深穴加工での一般的な課題は加工くずの除去である。穴 が深くなるほど，加工により生じたチップを外部に排出す るのが困難になる。ドリルにおいても, 放電加工において も, 深穴加工では間欠的に工具を引き戻してチップ排出を 行うことが広く行われている。このような工具引き戻しを 行わなくてよいのはパイプ電極で加工液を強制循環させる 電解加工や放電加工である。しかし，あまり小径になると 流量が激減し，噴流の効果が得られない，パイプが使えな い場合，工具に超音波などの振動を与えると効果があり， 最近はドリル加工 ${ }^{15)}$, 電解加工 ${ }^{16)}$ などにおいて超音波振動 の付与に関する研究が進みつつある. また，放電加工にお いてはパルス電源の改良による深穴対応も進められてい $ろ^{17)}$.

\section{5 難加工材料対応}

微細穴はわずかな酸化，污染，傷などで機能不良に陥り やすい. したがって, 耐薬品性や機械的強度の高い材料が 適する場合が多い。こうした材料は一般に加工し難いこと が多いという問題がある。また，複合材，アモルファスな どへの微細加工も徐々に必要性が高まりつつある.

難加工材料はそれぞれ個性が強いので, 従来微細加工に 適用されたことがないような加工法も含め, 各手法におけ る微細寸法への適用技術を切り開いていく必要がある.

\section{6 形状の多様化}

穴加工といえばドリルなどの回転工具で加工することが 多かったため，ストレートな丸穴のイメージが強いが，設 計上そのような穴が最適でない場合も少なくない. 角穴, 楕円形穴, 斜め穴, テーパ穴など, 形状の次元数の高い穴 への要求も少しずつ高まることが予想される.

異形穴に対応するには，より直径の小さい工具, または 微細かつ異形の工具が必要となる.つまり, 異形穴の微細 加工は丸穴加工よりさらに微細な加工技術の領域となる. 研究, 実用の両面で課題は山積しているといえよう.

\section{4. 微細穴の計測}

微細穴の計測は, 古くて新しいテーマであり, 現在でも 重要な研究課題となっている。 これは, 微細穴の内面の計 測は本質的な難しさをもっているためである. 穴の外側か らの計測には限界があり，内側から計測するには穴の直径 より小さいセンサまたはプローブヘッドしか, 穴の中に入 ることはできない. 特に, アスペクト比が大きい場合は, 外側からの計測が難しく，内面にセンサを入れる必要があ る。これを解決するには，穴を切断して測定する方法や， 穴に樹脂などを挿入しレプリカを取る方法などもあるが， 本解説では対象外とする。

\section{5. どんな計測法があるか}

微細穴計測は, 測定対象とする穴の仕様に依存してい る. 直径が $1 \mathrm{~mm}$ 以下であるか, アスペクト比がどのくら
いか，穴の底面が通し穴になっているか止まり穴になって いるかによって，適用できる計測方法が変わってくる．ま た, 内径計測だけを行うか, 内面の形状計測が必要かによ っても対応する手法が変わってくる ${ }^{18)}$.

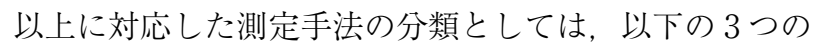
系統がある。

A. プローブを使う方法

これは，小さなプローブを微細穴に挿入する方法であ る ${ }^{19)}$ 23) . 微細穴側面への接触については, プローブの付 け根などに設置した検出器で検出する。このタイプでは, 接触式のプローブを用いる場合が多く, 測定対象の影響を 受けにくい汎用的な計測方法である. 測定可能な穴の内径 およびアスペクト比は，プローブの大きさに依存するが， かなり小型のプローブが開発できている.

B. 検出器を挿入する方法

これは, 検出器を微細穴に挿入する方法である。検出器 としては非接触の光センサが使われることが多い2425). 検 出器のサイズの制限により, 測定できる微細穴の内径が制 限される。一方，アスペクト比については，大きなものも 測定可能である.

C. 外部から測定する方法

これは, 微細穴の外部から光線を照射し, 小穴の内面を 測定する方法である ${ }^{26)}$ 。 この方法では非接触で測定可能で あるが，一般的に通り穴が対象となり，アスペクト比など の制限も大きい. 最近は, X 線 CT を工業分野で使う方法 も用いられるようになっている9 .

\section{1 プローブを使うタイプ}

5.1 .1 機械的な計測

接触的なプローブを使う方法では, $1 \mathrm{~mm}$ 以上の内径に ついては, 二点式および三点式内側マクロメータ, 球を 2 つに割った形の端子を使うシリンダゲージなどの一般的な 機械計測 ${ }^{18)}$ が適用できる.

5.1 .2 マイクロ CMM

マイクロ CMM (Coordinate Measuring Machine : 三次 元測定機）といわれるタイプの測定機の開発, 商用化が行 われている。これらの測定機は，一般的な三次元測定機を 高精度化すると同時に, 微細構造が測定できるプローブシ ステムを導入したものであり，プローブシステムの開発が 重要となっている.

IBS 社が開発したマイクロ CMM の ISRA400 では，400 $\mathrm{mm}$ までの測定対象に対して, サブマイクロメートルの精 度で三次元測定が可能となっている ${ }^{23)}$. プローブシステム triskelion は直径 $70 \mu \mathrm{m}$, 長さ $6 \mathrm{~mm}$ のプローブが, 半導 体プロセスで加工され, 複数の力七ンサをもつ検出部に接 続されている. プローブは三次元的な接触が検出可能で, 分解能 $3 \mathrm{~nm}$, 測定不確かさ $20 \mathrm{~nm}$ の測定が可能である.

同様のコンセプトのマイクロ CMM, ミットヨ MNanoCord では, 超音波微細プローブ UMAP103 を用いて いる ${ }^{22)}$.これは, 直径 $30 \mu \mathrm{m}$ のスタイラスで, 繰り返し 精度 $70 \mathrm{~nm}$ での測定が可能である. このプローブは, 共 
振周波数で振動していて，測定物に接触した場合の周波数 変化を検出している.

5.1.3 その他のプローブ

その他のプローブとして, 放電加工によって作った直径 数十 $\mu \mathrm{m}$ のプローブを使用した測定器の開発例がある ${ }^{20)}$. 放電加工を利用することで，複雑で微細なプローブを加工 することが可能となっている．光トラップを利用したプロ ーブも提案されている ${ }^{28)}$. 直径 $8 \mu \mathrm{m}$ のガラス球を，レー ザでトラップして測定対象に近づけることで，測定を行っ ている。トラップの条件などに制限があるが，非常に小さ な球で, 非常に力の小さい測定ができる可能性がある.

\section{2 検出器を挿入するタイプ}

光センサをもつ検出器によって, 非常に深い穴を測定可 能としている方法が提案されている ${ }^{23)}$. しかし, 検出器の 大きさから内径 $30 \mathrm{~mm}$ 以上の穴が対象であるが, 長さ数 $\mathrm{m}$ の深穴が測定可能である。このように検出器挿入夕イ プでは, 検出器の大きさに依存するため, $1 \mathrm{~mm}$ 以下の内 径の測定は難しい. 一方, 検出器の自由度が大きいため, 非常に深い穴，内面の形状などの測定が可能である.

先端を 45 度に研磨した光ファイバーを, 検出器として 利用する内径計測システムが提案されている ${ }^{25)}$. 内径の検 出は, 光ファイバーと内面それぞれからの光反射を, 絶対 測長できる干渉システム（低コヒーレンス干渉）で行って いる，検出器を挿入するタイプであるが，プローブタイプ と同じように，検出器の本体を外部に置くことができ，小 型化が可能となる。 この研究では, 光ファイバー径が 30 $\mu \mathrm{m}$ のものが試作されている.

\section{3 外部から測定するタイプ}

5.3.1 光線タイプ

光線タイプの例として, 光ファイバーを光源として微細 穴の内面を照射し，反射光を CCD カメラで検出する夕イ プが提案されている ${ }^{25)}$ 。この方法を利用することで，内径 $125 \mu \mathrm{m}$ のフェルールの内面の測定を精度 $0.1 \mu \mathrm{m}$ 程度で可 能としている. 光線タイプでは, 対象は限定されるが高速 な非接触測定が可能となる.

\subsubsection{X 線 CT}

$\mathrm{X}$ 線を使った非破壊検査は, 従来は欠陥検査を目的に 使用することが多かったが，最近は，工業用の X 線 CT （X線コンピュータトモグラフィ）が普及し, 欠陷検査だ けでなく，寸法などの計測が可能なシステムとしてメトロ ロジーCT が市販されている，Zeiss 社の X 線 CT 装置で は，デー夕を従来の三次元測定機と同様のソフトウェアで 計算が可能なシステムとなっている ${ }^{27)}$ 。測定範囲は径 300 $\mathrm{mm} \times 350 \mathrm{~mm}$ で, マイクロメートルオーダの小穴の内径 や内面の断層写真および形状が測定可能である。 X 線 CT は, 高分解能で広い寸法の範囲, アスペクト比の大きな測 定が可能であり，今後の有力な手法となると考えられる.

\section{6. 微細穴計測の現状と将来の方向}

\section{1 より微細穴への対応}

より微細穴への対応については，プローブタイプではプ ローブが接触することから強度などの問題で $10 \mu \mathrm{m}$ 以下 のプローブの開発は難しい. 有力な方法としては, 光ファ イバーを用いる方法と， X 線 CT を利用する方法である. 通し穴で素材や直径などが限定されている場合には, 光線 タイプなどを利用して高感度な方法が実現できる。

\section{2 高精度化と標準}

素材や直径などが限定されている場合には，比較測定な どの相対的な手法による高精度化が可能となる。プローブ タイプの場合には, 方向性やプローブの真球度などが問題 となる，X 線 CT の場合には，素材やデー夕処理の問題か らやはり, 絶対精度を向上させるのは難しい。

どの手法においても, 精度評価が重要となる。精度評価 には，トレーサビリティが取れている標準が必要である. 内径の場合にはリングゲージが標準となるが，一般に供給 されているリングゲージは直径が $1 \mathrm{~mm}$ くらいからであ り, 内径の校正精度もサブマイクロメートルくらいとなっ ている。より小さな内径で, 高精度な標準の開発が重要と なる.

\section{3 形状測定への対応}

内径だけでなく，形状を測定する要求も多くなってい る。これには, 必要とする分解能によって対応が違ってく る. 粗さなどの非常に細かい分解能で測定が要求される場 合への対応は，かなり難しい. プローブタイプではプロー ブの直径, 光線タイプでは光のスポット径, X 線 CT では ボクセルサイズが問題となり, 簡単な解決方法はない. 沉 用的な形状測定では，プローブタイプが対象の表面性状の 影響を受けにくく有利であるが，分解能は高くできない. 全体の形状を高速に測定するには光線タイプ，X線 CT が 有利である。

\section{4 今後の方向性}

微細穴計測手法について，機械的な手法から最新の X 線 CT まで，いくつかの手法について概要を説明した。微 細穴計測は，まだ多くの課題が残っていて，沉用的な手法 が存在しない. 小型プローブを微細加工技術で作成し，マ イクロ CMM などで活用する方向が一つの有力な方法で あり，うまく普及が進めばプローブを安価で提供できる可 能性がある。一方，光センサを利用した方法は，沉用的よ りは, 限定された部品に対して高速, 高精度を目指す方法 として, 個別な開発が期待される. 最後に, X 線 CT は有 力な手法で, 今後にデータ処理ソフトウェアの開発が進 み，精度評価ができるようになれば，工業的な利用が多く の微細部品に対して行われるようになると思われる.

\section{参 考 文 献}

(実用状況を示すためカタログなども含めた. カタログの最新情報は ホームページ等で確認されたい.） 
1）伊藤精工(株), カタログ, (2006).

2)（株)信栄テクノ, カタログ, (2010).

3）(株)エレニックス, ホームページ, (2012).

4) SARIX SA, カタログ, (2006).

5) MMTC, ホームページ, (2012).

6) B.J. Park, B.H. Kim and C.N. Chu : The Effects of Tool Electrode Size on Characteristics of Micro Electrochemical Machining, Annals of the CIRP, 55, 1 (2006) 197-120.

7）(株)ピーエムティー, カタログ, (2009).

8）新東ブレーター(株), カタログ, (2006).

9）(株)ソディック，カタログ，(2009).

10）大和テクノシステムズ，カタログ，(2007).

11) SmalTec International，カタログ，(2009).

12）中田製作所(株)，ホームページ，(2012）.

13）(株)化繊ノズル製作所，カタログ，(2009）.

14）東レ・プレシジョン(株), カタログ, (2007)

15) M. Aziz, O. Ohnishi and H. Onikura : Novel Micro Deep Drilling Using Micro Long Flat Drill with Ultrasonic Vibration, Precision Engineering, 36 (2012) 168-174.

16) I.S. Yang, M.S. Park and C.N. Chu : Micro ECM with Ultrasonic Vibrations Using a Semi-cylindrical Tool, Int. J. Prec. Eng. and Manufacturing, 10, 2 (2009) 5-10.

17）浅井厳慶, 岡根正裕：最新細穴放電加工機の新技術, 型技術, 26, 7 (2011) 96-97.

18）高増潔：微細管内径および内面の計測, 砥粒加工学会誌, 56,2 (2012) 94-97.
19）二点式/三点式内側マイクロメータ，シリンダゲージ，ミットヨ ホームページ http://www.mitutoyo.co.jp/

20）山本正樹, 山口恵作, 青木新一郎：バイブロスキャニング法を 用いた微細形状測定システムの開発, 精密工学会誌, 67,2 (2001) 251-255.

21）村上洋, 甲木昭雄, 鬼鞍宏奠他：光ファイバプローブを用いた 微小径穴形状精度測定システムの開発 (第 1 報), 精密工学会 誌, 75, 12 (2009) 1476-1481.

22）微細形状計測システム M-NanoCoord シリーズ，ミットヨホー ムページ http://www.mitutoyo.co.jp/

23) ISARA400, IBS 社ホームページ http://www.ibspe.com/

24）甲木昭雄, 村上洋, 鬼鞍宏奠他 : オートコリメーション方式深 穴形状精度測定システムの開発（第 1 報），精密工学会誌， 73, 7 (2007) 813-817.

25）松井健太, 高橋哲, 高増潔, 松本弘一：タンデム低コヒーレン ス干渉を用いた微小内径の非接触測定技術の開発（第 3 報）, 2011 年度精密工学会秋季大会学術講演会講演論文集, 2011, N63.

26）秋山伸幸，小林典之他：小径穴内面形状計測装置の開発，精密 工学会誌, 68, 7 (2002) 967-971.

27) X 線 CT 三次元測定機 METROTOM, Zeiss 社ホームページ http://www.zeiss.co.jp/

28）高谷裕浩, 佐藤憲章, 高橋哲, 三好隆志, 清水浩貴, 渡辺万次 郎：ナノCMM レーザトラッピングプローブに関する研究（第 1 報), 精密工学会誌, 66, 7 (2000) 1081-1086. 